\title{
Antibacterial Activity of Endophytic Fungi Isolated from Mangrove Plant Sonneratia griffithii Kurz
}

\author{
Dian Handayani ${ }^{1 *}$, Harrizul Rivai ${ }^{1}$, Monica Hutabarat ${ }^{2}$, Roslaili Rasyid ${ }^{3}$ \\ ${ }^{1}$ Faculty of Pharmacy, Andalas University, Padang 25163, Indonesia. \\ ${ }^{2}$ School of Pharmacy, Padang, Indonesia. \\ ${ }^{3}$ Faculty of Medicine, Andalas University, Padang 25163, Indonesia.
}

\begin{tabular}{l} 
ARTICLE INFO \\
\hline Article history: \\
Received on: 05/10/2016 \\
Accepted on: $18 / 12 / 2016$ \\
Available online: $30 / 04 / 2017$ \\
\hline Key words: \\
Endophytic fungi, mangrove, \\
Sonneratia griffithii Kurz, \\
antibacterial activity.
\end{tabular}

\begin{abstract}
The aim of this study was focused on the antibacterial activity of endophytic fungi from leaf, bark and root of mangrove Sonneratia grifithii Kurz, collected from Bungus, West Sumatra. Isolation of endophytic fungi was based on direct planting method with sabouraud dextrose agar (SDA) as growth medium. Twelve isolates fungi strains were obtained from this mangrove. They were cultivated on sabouraud dextrose broth (SDB) for 4 weeks and they are fractioned using ethyl acetate and butanol. Ethyl acetate and butanol extracts were analyzed for antibacterial activity. The fungi strains which showed the maximum activity were identified by macroscopic and microscopic examination. Twelve (50\%) extracts of endophyte fungi strains were able to inhibit the growth of pathogenic bacteria such as, Staphylococcus aureus and Escherichia coli. Endophytic fungi strains that have higher antibacterial activity derived from the root than from leave and bark Sonneratia griffithii Kurz. This work concluded that endophytic fungi strains of Sonneratia griffithii Kurz can be developed as a new source of antibiotic compounds.
\end{abstract}

\section{INTRODUCTION}

Mangrove is a plant found in tidal areas such as coast of tropical and sub-tropical regions which protected. This plant consists of tree species Avicennia, Sonneratia, Rhizophora, Bruguiera, Ceriops, Lumnitzera, Excoecaria, Xylocarpus, Aegiceras, Scyphyphora and Nypa. In Indonesia, the diversity of mangrove species that grows between islands is much different. Mangrove species most found in Java and Sumatra, compared to other islands, where 202 mangrove species are known, 166 of them are found in Java, 157 kinds of Sumatra, 150 species in Borneo, 142 species in Irian Jaya, 135 types in Sulawesi, and 120 species in the Lesser Sunda islands. S. grifithii Kurz is a plant widely distributed along West Sumatra coastlines and belonging to family Lythraceae (Giesen, et al., 2007). Mangroves are one source of traditional medicine in Indonesia. This plant is reported as host a rich source of fungal. Endophytic fungi derived from mangrove ecology is the second largest group after the

\footnotetext{
* Corresponding Author

Dian Handayani, Faculty of Pharmacy, Andalas University, Padang 25163, Indonesia. Email: dianh_17 @ yahoo.com
}

endophytic fungi from the sea (Sridhar, 2004). These endophytic fungi have proven capable of producing secondary metabolites that are very interesting based bioactivity and chemical structures, such as antibiotics, antifungal, immunosuppressant and anticancer compounds (Strobel, 2002; Strobel and Daisy, 2003; Alfaro and Boyman, 2011). Researches related to potential of mangrove as a producer of medicinal compounds have been much carried out. However, only few studies have been reported on fungal endophyte and its potential to produce bioactive compounds from mangrove plant of West Sumatra, Indonesia. Based on this potential, we are interested to examine the endophytic fungi which were isolated from leaf, bark and root of $S$. griffithii Kurz which grows in West Sumatra, Indonesia and to test its antibacterial activity.

\section{MATERIAL AND METHODS}

\section{Material}

The fresh leaf, bark, and root of S. griffithi Kurz were collected from Bungus coast, West Sumatra, Indonesia for the investigation of the endophytic fungi. The plant was brought to the laboratory in sterile bags. 


\section{Isolation of Endophytic Fungi}

Samples (leaf, bark, and root of plant) were used after the sterilization of its surfaces and then planted directly in the growth medium. The sample is washed with running water for 10 minutes and cut into 4 pieces with a length of each of the pieces of approximately $1 \mathrm{~cm}$. Stratified sample pieces are sterilized by dipping in $70 \%$ ethanol for 1 minute, put it in a bleach solution ( $\mathrm{NaOCl} 5.3 \%$ ) for 5 minutes, and dipped again into $70 \%$ ethanol for 30 seconds. Each piece is placed on SDA media to stick to the position of parts of the surface so that the medium. Incubation is carried out at room temperature for 3-5 days. After 5 days, the plates were examined and the pure culture was isolated on pure agar plate.

\section{Cultivation of fungi isolates for antimicrobial activity screening}

In order to obtain secondary metabolites, the pure culture of each endophytic fungi was grown in $100 \mathrm{~mL}$ of SDB media and incubated at $27^{\circ} \mathrm{C}$ for 30 days.

\section{Extraction of secondary metabolites from fungi isolates}

A total of $60 \mathrm{~mL}$ of liquid culture fungi was fractionated with ethyl acetate in the ratio 1: 1 Ethyl acetate extract was then separated from the culture medium using a funnel and performed three repetitions. Fungi liquid culture returned subsequently was fractionated with butanol as much as $20 \mathrm{~mL}$ with three repetitions. Ethyl acetate and butanol extract was then evaporated in vacuo with a rotary evaporator.

\section{Screening for antimicrobial activity}

For screening of antimicrobial activity EtOAc and buthanol extracts of endophytic fungi was tested against Staphylococcus aureus, Escherichia coli, and Candida albicans using the paper disk method. One pieces of $6 \mathrm{~mm}$ sterile paper disk was soaked in each of EtOAc extract (10 mg/ml in DMSO). Paper disks were also inoculated with DMSO (negative control), Oxytetrasiklin (20 mg.ml ${ }^{-1}$ in distilled water) and Clotrimazol (500 $\mu \mathrm{g} \cdot \mathrm{ml}^{-1}$ in distilled water) as positive controls. The disk was placed on the surface of the medium containing $10^{5}$ cells of bacteria and fungi test strain. The plates were incubated at $37{ }^{\circ} \mathrm{C}$ for 24 hours for bacteria and at a temperature of $25^{\circ} \mathrm{C}-27^{\circ} \mathrm{C}$ for 5-7 days for fungi. The width of inhibition zones was measured. Each treatment consisted of three replicates. The experiment was repeated twice.

\section{RESULTS AND DISCUSSION}

A total of 12 strains of endophytic fungi were isolated from the leaf, bark and root of mangrove S. griffthii Kurz. Each of these fungal strains is cultivated in sabouraud dextrose broth (SDB) for 4 weeks and fractionated using ethyl acetate and butanol, yielding a total of 24 extracts of ethyl acetate and butanol. An initial screening of these extracts for antibacterial activity against $S$. aureus, E. coli and $C$. albicans was carried out. The results of the antibacterial activity showed that 12 fractions of endophytic fungi active against $S$. aureus and 12 fractions active against $E$. coli, but no one had the activity against $C$. albicans. The fungal isolate which had an average of the highest diameter of growth inhibitory against $S$. aureus was a butanol fraction $\mathrm{SgA} 1$ with diameter inhibitory of $14.8 \mathrm{~mm}$, while fungal isolate that having the highest inhibitory effects on the growth of $E$. coli was a butanol fraction SgA4 with diameter inhibitory of $15.75 \mathrm{~mm}$ (Table 1).

Table 1: Antibacterial activity of endophytic fungi extracts of S. griffthii Kurz.

\begin{tabular}{|c|c|c|c|c|c|c|}
\hline \multirow[b]{2}{*}{ No } & \multirow[b]{2}{*}{ Sample Code } & \multirow[b]{2}{*}{ Extract } & \multirow{2}{*}{ 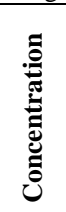 } & \multicolumn{3}{|c|}{$\begin{array}{c}\text { Zone of inhibition } \\
(\mathbf{m m})\end{array}$} \\
\hline & & & & SA & EC & CA \\
\hline \multirow{6}{*}{1} & \multirow{6}{*}{$\begin{array}{c}\mathrm{SgA}_{1} \\
\text { (Aspergillus } \\
\text { fumigatus) }\end{array}$} & \multirow{3}{*}{$\begin{array}{l}\text { Ethyl } \\
\text { Acetate }\end{array}$} & $1 \%$ & - & - & - \\
\hline & & & $3 \%$ & 8 & - & - \\
\hline & & & $5 \%$ & 9 & - & - \\
\hline & & \multirow{3}{*}{ Butanol } & $1 \%$ & 9.1 & - & - \\
\hline & & & $3 \%$ & 12.25 & - & - \\
\hline & & & $5 \%$ & 14.8 & - & - \\
\hline \multirow{6}{*}{2} & \multirow{6}{*}{$\begin{array}{c}\mathrm{SgA}_{2} \\
\text { (Candida } \mathrm{sp}_{1} \text { ) }\end{array}$} & \multirow{3}{*}{$\begin{array}{l}\text { Ethyl } \\
\text { Acetate }\end{array}$} & $1 \%$ & - & - & - \\
\hline & & & $3 \%$ & - & - & - \\
\hline & & & $5 \%$ & - & - & - \\
\hline & & \multirow{3}{*}{ Butanol } & $1 \%$ & - & - & - \\
\hline & & & $3 \%$ & - & - & - \\
\hline & & & $5 \%$ & - & - & - \\
\hline \multirow{6}{*}{3} & \multirow{6}{*}{$\begin{array}{c}\mathrm{SgA}_{3} \\
\text { (Aspergillus niger) }\end{array}$} & \multirow{3}{*}{$\begin{array}{l}\text { Ethyl } \\
\text { Acetate }\end{array}$} & $1 \%$ & - & - & - \\
\hline & & & $3 \%$ & - & - & - \\
\hline & & & $5 \%$ & - & - & - \\
\hline & & \multirow{3}{*}{ Butanol } & $1 \%$ & 9 & 9 & - \\
\hline & & & $3 \%$ & 9.2 & 9.4 & - \\
\hline & & & $5 \%$ & 12 & 11.8 & - \\
\hline \multirow{6}{*}{4} & \multirow{6}{*}{$\begin{array}{c}\mathrm{SgA}_{4} \\
\text { (Candida } \mathrm{sp}_{2} \text { ) }\end{array}$} & \multirow{3}{*}{$\begin{array}{l}\text { Ethyl } \\
\text { Acetate }\end{array}$} & $1 \%$ & - & - & - \\
\hline & & & $3 \%$ & - & 11 & - \\
\hline & & & $5 \%$ & 12 & 12 & - \\
\hline & & & $1 \%$ & - & 10.6 & - \\
\hline & & Butanol & $3 \%$ & - & 12.4 & - \\
\hline & & & $5 \%$ & - & 15.75 & - \\
\hline & & & $1 \%$ & - & - & - \\
\hline & & Ethyl & $3 \%$ & - & - & - \\
\hline & & & $5 \%$ & - & - & - \\
\hline 5 & $\mathrm{SgKB}_{1}$ & & $1 \%$ & - & 8.85 & - \\
\hline & & Butanol & $3 \%$ & 10.15 & 9.8 & - \\
\hline & & & $5 \%$ & 10.2 & 10.2 & - \\
\hline & & & $1 \%$ & - & - & - \\
\hline & & Ethyl & $3 \%$ & 8 & 8 & - \\
\hline & & & $5 \%$ & 9.5 & 10 & - \\
\hline 6 & (Penicillium sp) & & $1 \%$ & - & - & - \\
\hline & & Butanol & $3 \%$ & - & - & - \\
\hline & & & $5 \%$ & - & - & - \\
\hline & & & $1 \%$ & - & - & - \\
\hline & & $\begin{array}{l}\text { Ethyl } \\
\text { Acetate }\end{array}$ & $3 \%$ & - & - & - \\
\hline 7 & $\mathrm{SgKB}_{3}$ & & $5 \%$ & - & - & - \\
\hline t & $\left(\right.$ Cladosporium $\left.\mathrm{sp}_{1}\right)$ & & $1 \%$ & 11.75 & 8.1 & - \\
\hline & & Butanol & $3 \%$ & 12.5 & 9.1 & - \\
\hline & & & $5 \%$ & 12.55 & 9.85 & - \\
\hline & & & $1 \%$ & - & - & - \\
\hline & & $\begin{array}{l}\text { Ethyl } \\
\text { Acetate }\end{array}$ & $3 \%$ & 10.5 & 8.5 & - \\
\hline 8 & $\mathrm{SgKB}_{4}$ & & $5 \%$ & 12 & 10 & - \\
\hline 8 & (Aspergillus niger) & & $1 \%$ & - & - & - \\
\hline & & Butanol & $3 \%$ & - & 8.35 & - \\
\hline & & & $5 \%$ & - & 8.55 & - \\
\hline 9 & $\mathrm{SgD}_{1}$ & Ethyl & $1 \%$ & - & - & - \\
\hline 9 & $\left(\right.$ Candida $\left.\mathrm{sp}_{3}\right)$ & Acetate & $3 \%$ & 9 & 8 & - \\
\hline
\end{tabular}




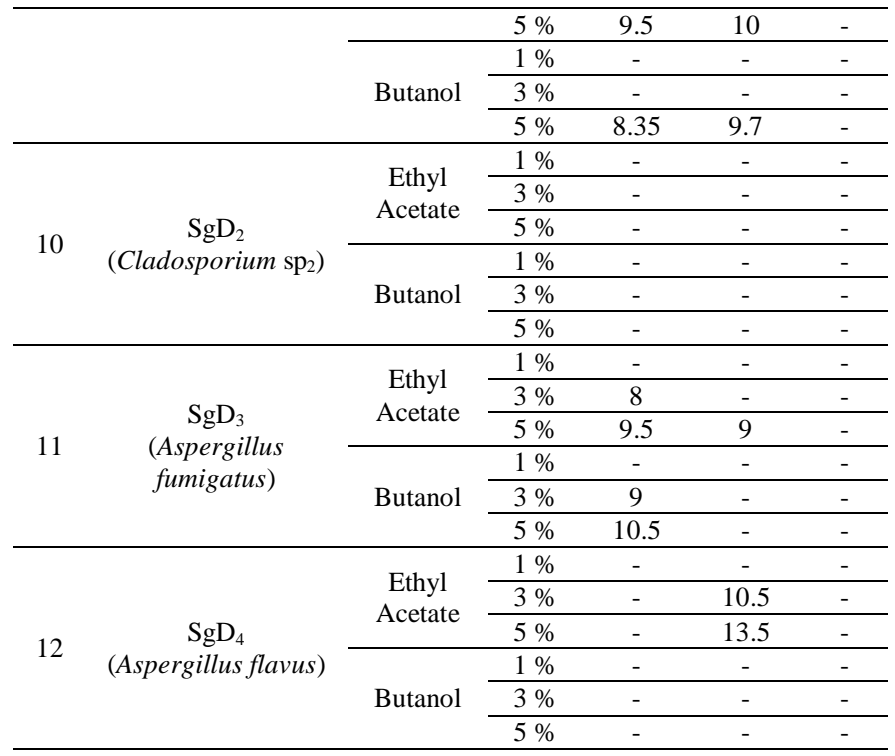

: negative, SA : S. aureus, EC: E. coli, CA : C. albicans

Fungal endophytes were selected for futher characterization and identification based on Brigitte (1980). Macroscopic examination includes a visual observation to the form colony or hypha, surface and reverse colony color, and colony texture. While on microscopic examination was carried out by observing the characteristic of the spores or conidia, and reproductive structures (sexual and asexual) under a light-field microscope. From the results of characterization are known that the isolates of endophytic fungi are Aspergillus fumigatus, Candida sp1, Aspergillus niger, Candida sp2, Candida sp3, Cladosporium sp1, Aspergillus flavus, Penicillium sp, Cladosporium sp2, and Aspergillus sp1 (Brigitte, 1980).

Endophytic or fungi associated with marine algae, sea grass and mangroves, fungi cohabiting with marine invertebrates, especially corals and sponge suspected to be the actual producer of many bioactive compounds in marine plants and animals. Our earlier studies showed that the endophytic fungi are a potential source of antibiotics and anticancer compounds. (Handayani et al., 2015a; Handayani et al., 2015b; Handayani et al., 2016; Harrizul et al., 2016).

In previous study, fungi of Aspergillus flavus and Aspergillus niger which were isolated from soil can inhibit the growth of S. aureus and E. coli (Makut, and Owolewa, 2011). Fungi Penicillium sp and Cladosporium sp which were isolated from the leaves and stems of the plant Suaeda maritime and Suaeda monoica have activity against pathogenic bacteria gramnegative $E$. coli using agar diffusion method (Kalyanasundaram, et al., 2015). Other studies mention that endophytic fungi Penicillium sp has an activity as antimicrobial against Listeria monocitogenes ATCC 19115, Streptococcus pyogenes ATCC 19615, Salmonella typhimurium ATCC 13311, Candida albicans ATCC 18804 and Bacillus cereus ATCC 11778, and Listeria sp (Petit, et al., 2009).

The results of the antimicrobial activity testing showed that endophytic fungi extract derived from the roots were better than those derived from the bark and leaves. Type of endophytic fungi from different plant parts of the host plants, appeared to contain different isolates. The roots are living in the extreme area of ups and downs of sea water and the soft soil with high organic content trigger fungi habitat in plants (endophyte) produces unique metabolites in response to the unusual habitat. The physical factor that influence the fungi most are salinity and $\mathrm{pH}$, low water potential, high concentrations of sodium ions, low temperature, and high hydrostatic pressure. The host of fungi endophyte that grows in a hard and experienced many challenges of physical and chemical is a potential source for discovery endophytic fungi (Raghukumar, 2008).

\section{CONCLUSION}

Based on research conducted, it can be concluded that endophytic fungi derived from mangrove are a source of antibiotic compound. An organ of plants that contain most of endophytic fungi is the root, in comparison with leaves and bark. This research needs to be continued as an attempt of new drugs discovery which is useful in fields of pharmaceuticals and health.

\section{ACKNOWLEDGEMENT}

Financial support and sponsorship: This research was funded by BOPTN of Andalas University, Padang, Indonesia, in project of "Hibah Klaster Riset Guru Besar”, No. 524/XIV/A/UNAND-2016.

Conflict of Interests: There are no conflicts of interest.

\section{REFERENCES}

Alfaro AP, Boyman P. Hidden fungi, emergent properties: endophytes and microbiomes. Annu. Rev. Phytopathol. 2011; 49:291-315.

Brigitte G. Kompendium der medizinischen mykologie. 1980, Berlin Hamburg. Verlag Paul Parey.

Giesen W, Wulffraat S, Zieren M and Schoelten L. Mangrove guidebook for Southeast Asia, 2007. FAO and Wetlands International, Dharmasarn, 186pp.

Handayani D, Ahdinur, RF, and Rustini R. Antimicrobial Activity of Endophytic Fungi from Marine Sponge Haliclona fascigera. Journal of App Pharm Sci, 2015b; 5(10): 154-156.

Handayani D, Ornando R and Rustini, Antimicrobial Activity Screening of Symbiotic Fungi from Marine Sponge Petrosia nigrans collected from South Coast of West Sumatra Indonesia, International Journal of Pharmacognosy and Phtochemical research, 2016; 8(4): 623625 .

Handayani D, Sandrawaty N, Murniati M, and Regina R. Screening of Endophytic Bacteria Isolated from Marine Sponge Haliclona fascigera for Inhibition against Clinical Isolates of Methicillin Resistant Staphylococcus aureus (MRSA). J. of App Pharm Sci, 2015a; 5(9): 139142.

Harrizul R, Asia A, Wahyuni A, Allen Y, Handayani D, Yufri A, Marlina M and Djamaan A. Isolation of endophytic bacteria from bark, Leaf and Pericarp of Mangosteen (Garcinia mangostana L) and testing of the antimicrobial activity. Research Journal of Pharmaceutical, Biological and Chemical Sciences, 2016; 7(1):1910-1920.

Kalyanasundaram I, Jayaprabha N, Srinivasan M. Antimicrobial activity of endophytic fungi isolated and identified from salt marsh plant in Vellar Estuary. Journal of Microbiology and Antimicrobials. 2015; 7(2):13-20.

Makut MD, Owolewa OA. Antibiotic-producing fungi present in the soil environment Of Keffi Metropolis, Nasarawa State, Nigeria. 
Trakia Journal of Sciences. 2011; 9(2): 33-39.

Petit P, Lucas EMF, Abreu LM, Pfenning LH, Takahashi JA. Novel antimicrobial secondary metabolites from a Penicillium sp. isolated from Brazilian cerrado soil. Electronic Journal of Biotechnology. 2009; 12(4):1-9.

Raghukumar, C. Marine fungal biotechnology: an ecological perspective. Fungal Deversity. 2008; 31:19-35.

Sridhar KR. Mangrove fungi in India. Current Science, 2004; $86: 1586-1587$

Strobel, GA, Daisy B. Bioprospecting for microbial endophytes and their natural products. Microbiology and Molecular Biology Reviews. 2003; 67 (4):491-502.

Strobel, GA. Microbial gifts from rain forests. Can. J. Plant Pathol. 2002; 24:14-20

\section{How to cite this article:}

Handayani D, Rivai H, Hutabarat M, Rasyid R. Antibacterial Activity of Endophytic Fungi Isolated from Mangrove Plant Sonneratia griffithii Kurz. J App Pharm Sci, 2017; 7 (04): 209-212. 